\title{
Interpretation of gravity data to delineate structural features connected to low-temperature geothermal resources at Northeastern Portugal
}

\author{
Patricia Represas ${ }^{\text {a,b,* }}$, F.A. Monteiro Santos ${ }^{\text {b }}$, José Ribeiro ${ }^{\text {b }}$, Joana A. Ribeiro ${ }^{\text {b }}$, Eugénio P. Almeida ${ }^{\text {b,c }}$, \\ Rui Gonçalves b,c, Mário Moreira ${ }^{\text {b, d }}$, L.A. Mendes-Victor ${ }^{\text {b }}$ \\ a Laboratório Nacional de Energia e Geologia, Amadora, Portugal \\ b University of Lisbon-IDL, Ed C8 Campo Grande, Lisboa, Portugal \\ ' Instituto Politécnico de Tomar, Tomar, Portugal \\ ${ }^{\mathrm{d}}$ Instituto Superior de Engenharia de Lisboa, Lisboa, Portugal
}

\section{A R T I C L E I N F O}

\section{Article history}

Received 4 December 2012

Accepted 11 February 2013

Available online 24 February 2013

\section{Keywords:}

Gravity data

Bouguer anomaly

Gravity derivative

3D inversion

Hydrothermal system

Portugal

\begin{abstract}
A B S T R A C T
A great number of low-temperature geothermal fields occur in Northern-Portugal related to fractured rocks. The most important superficial manifestations of these hydrothermal systems appear in pull-apart tectonic basins and are strongly conditioned by the orientation of the main fault systems in the region. This work presents the interpretation of gravity gradient maps and 3D inversion model produced from a regional gravity survey. The horizontal gradients reveal a complex fault system. The obtained 3D model of density contrast puts into evidence the main fault zone in the region and the depth distribution of the granitic bodies. Their relationship with the hydrothermal systems supports the conceptual models elaborated from hydrochemical and isotopic water analyses. This work emphasizes the importance of the role of the gravity method and analysis to better understand the connection between hydrothermal systems and the fractured rock pattern and surrounding geology.
\end{abstract}

(c) 2013 Elsevier B.V. All rights reserved.

\section{Introduction}

There is a great scientific and economic interest in surface manifestations of geothermal fluid circulation all over the world. Hydrogeological, geochemical, isotopic, and geophysical data are commonly used to construct an image of geothermal systems, enabling decision making regarding important issues that will influence the development of the future exploitation of such resources (Dickson and Fanelli, 2003).

Low-temperature geothermal fields occur in Northern Portugal (Marques et al., 2010) associated with highly fractured rocks. The area under study is a part of the large morphostructural unit called Hesperic Massif, in the Galicia-Trás-os-Montes Zone (Fig. 1). This region shows evidences of multiple deformation events compatible with the Hercynian cycle, which comprises three deformation phases, and also with the alpine cycle (Ribeiro, 1974). Several authors (e.g. Arthaud and Matte, 1975; Ribeiro et al., 2007) outline three main Late-Variscan strike-slip fault systems in the northern sector of Iberia: the dominant NE-NNE (always sinistral), the subordinate NW-NNW (Late-Variscan dextral) and the conjugate E-ENE (mainly sinistral). The geometry and kinematics of the $\mathrm{N}-\mathrm{S}$ maximum compressive stress field were

\footnotetext{
* Corresponding author at: Laboratório Nacional de Energia e Geologia, Amadora, Portugal. Tel.: + 351214705514 .

E-mail address: prepresas@fc.ul.pt (P. Represas).
}

responsible for the development of the process of active deep-crustal shortening and related main geomorphic patterns in Iberia (Vicente and Vegas, 2009). There are also evidences of neotectonic activity in the more recent sedimentary formations.

Fig. 2 shows a sketch of the geological setting of the area. The schistgraywacke complex (SGC) is the oldest identified unit (ante-Ordovician) (Pereira, 2006). It was formed by the deposition of a sedimentary sequence in the intracontinental trench related to the distensive process of oceanic birth. When the tension field changed from a distensive to a compressive regime, these sedimentary sequences were deformed originating the now schist-graywacke complex.

The schist, graywacke and psammite complex (SGP) dates from the lower Siluric (Ribeiro, 1974), while the turbiditic sequence of the Santos e Curros Formation (T) was deposited in the lower Devonic (Pereira, 2006). By the end of the Hercynian cycle, episodes of magma ascension occurred, resulting in the installation of granitic formations (STG). These formations are, for the most part, syntectonic with the third deformation phase of the Hercynian orogeny (D3). However there are occurrences, in circumscribed masses, of apparently post tectonic granites (PTG). In fact, these granites do not present evidences of intersection with D3. Their installation is related to a tardi-Hercynian fracturation trending NNE-SSW (Pereira, 2006).

The main geologic feature present in this area is the segment of the NNE-SSW Penacova-Regua-Verin fault (PRVf) zone (Baptista, 1998; Cabral, 1995; Lourenço, 2006). This structure stretches for $200 \mathrm{~km}$, from Penacova to the south, northward to Verin, Galicia. In tardi- 